\title{
Virtual Learner 2.0: A Technique to Evaluate the Importance of Web 2.0 based e-Learning Application
}

\author{
Kanwal Yousaf \\ Department of Software \\ Engineering \\ University of Engineering and \\ Technology, Taxila
}

\author{
Muhammad Nadeem \\ Majeed \\ Assistant Professor of Software \\ Engineering \\ University of Engineering and \\ Technology, Taxila
}

\author{
Adeel Akram, PhD. \\ Dean Faculty of \\ Telecommunication \& \\ Information Engineering \\ University of Engineering and \\ Technology, Taxila
}

\begin{abstract}
Indeed e-learning provides gateway to better educational system for learners. In order to enhance socialization and sharing of knowledge among existing e-learning applications, Web 2.0 based tools can be integrated and utilized in these applications. This research paper is also related to evaluate the significance and compatibility of Web 2.0 tools in education. For this purpose a methodology is proposed and a prototype system is developed. The proposed system is named as Virtual Learner 2.0. Virtual Learner 2.0 is a Web 2.0 based e-learning application and socializes around learners. It is a combination of different Web 2.0 tools. Whenever applications have been developed by using Web 2.0 based approaches, especially by using tagging, video podcasting and discussion forum, always grasp attention of diversified community. Similarly, Virtual Learner 2.0 allows its learners to find out the effectiveness of video podcasting and discussion forum in any educational web applications. Secondly, this application is a better source to observe the searching efficiency of tags and tags cloud for data contents. By evaluating this application it is proved that learners seek more progress in learning through Web 2.0 based tools instead of utilizing the traditional learning techniques. Most importantly Virtual Learner 2.0 facilitates the learners with solution of better, reliable and enhanced course management system (CMS).
\end{abstract}

\section{General Terms}

Web 2.0, e-learning, Virtual Learner 2.0, Video Podcasting, Tagging, Tags Cloud

\section{INTRODUCTION}

Our life has deeply been penetrated into variety of technologies. The popularity graph of technology is elevating with the passage of time and no one can deny importance of technology. It means that technology has great impact on our every aspect of life. Learning process can be improved by adopting such tools and techniques as this process relies on acquiring knowledge, skills and understandings. These technologies help educators to improve their technical skills in most effective and efficient manner. E-Learning is an example of this combination of technology and education. Surprisingly e-learning has changed the traditional class room based education. E-learning introduces the concept of new environment named as virtual learning environment (VLE). Distant learning or virtual learning relates to make some significant changes in teaching. So that it can become beneficial for the distant educators or learners. Virtual learning has some most prominent advantages such as [1]: a) It provides an opportunity for students or learners to update their skills.

b) It improves the level of educational system by providing quality education to learners through web.

c) It is a source of balancing in-equalities between students from different background.

d) It provides socialized platform through which learners can communicate and collaborate with other learners at any time [1].

As the matter of fact, Web 2.0 based e-learning allows its learners to publish and exchange information and skills through communication. The terminology e-learning 2.0 emerges as a new dimension for learning followed by variety of Web 2.0 based tools. In traditional learning, students have been assigned with a bounded role towards education by following the formal procedures of learning. In contrast, e-learning particularly Web 2.0 based e-learning emphases on social learning and make all the possible use of Web 2.0 tools [2]. It also provides an informal approach towards education. O'Reilly defined usage of Web 2.0 in the form of different tools. These tools are wikis, blogs, social networking, tags, discussion forums, RSS feeds and podcasting etc [3] also explained with the help of Figure 1.

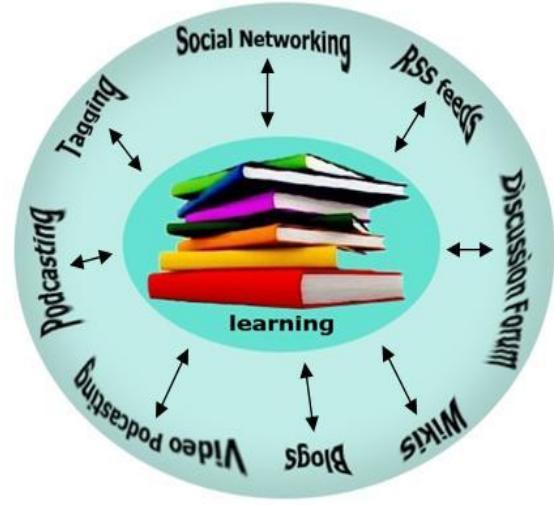

Fig 1: Web 2.0 based e-learning

All these tools are the very useful to modify user interactivity with the system and application. The main ingredients for the popularity of web 2.0 based applications along with the use of blog, wiki pages and class discussion has become increasingly popular among different business companies and education institutes.

The rest of the paper is distributed as follows. Section II explained about different researchers' perception about Web 2.0 based e-learning applications instead of following traditional approaches of learning. The flaws in already existing course 
management systems are mentioned in Section III. We analyzed the survey gathered from professional experts, teachers and students in Section IV and methodology is proposed. The proposed methodology, named as Virtual Learner 2.0, is explained in Section V. We also evaluated our proposed methodology by comparing it with already existing e-learning applications in same section. The research paper is concluded in last Section VI.

\section{LITERATURE REVIEW}

Yang [4] researched on the community learning via e-learning applications. E-learning applications are enriched with learning contents. These applications are the mixture of hypermedia, multimedia and other materials which can be accessed through computers or network. It also provides more flexible and efficient learning approach by facilitating its learners to seek knowledge from anywhere and at any time. He concluded his research by emphasizing on the use of different digital learning techniques in order to meet the residents learning requirements to its highest level.

Chen [5] explained about the rapid change of traditional learning into positive, inquisitive and collaborative learning. According to him, it is very important to make use of advance technology and the idea of e-learning for better communication and motivation of straining learners in acquiring some special skills and knowledge.

Papanikolaou and Mavromoustakos [6] proposed architecture for developing Web 2.0 based e-learning applications. This architecture follows SpiderWeb software development process model. In this architecture, trainers have the authority of selecting Web 2.0 tools. The selection of tools depends upon targeted audience, nature of course and educational objectives. According to these researchers, the use of Web 2.0 tools in elearning applications will be helpful for any student to keep his/her pace with the rest of the class. Previously, Web 2.0 tools were not developed for the purpose of gaining knowledge but these tools can become a part of collaborative learning system.

Copley [7] conducted a survey from the undergraduate and graduate level students. He provided students with audio and video podcast material and allowed them to evaluate the effectiveness of podcasting and video-podcasting in terms of higher education. These students tried both audio and video podcast materials. Almost all students had cast their vote for video podcasting. Students reviewed video podcasting, Web 2.0 tool, as a brilliant source of lecture revision. They stated that they can have all the record of lectures. However, the design and development of a "Stand alone" podcast material requires technical skills.

Similarly Shim, Shropshire, Park, Harris, and Campbell [8] investigated the comparison between web casting and video podcasting. Web casting is basically synchronous broadcasting while podcasting is different from it. Podcasting contains an important feature named as RSS (Real simple Syndication). In RSS, subscribers can get the feeds of their own choice by selecting the specific content. The authors suggested that podcasting should not be assumed as a tool to replace the traditional class room system. Rather it should be considered as a source for providing the back-up to traditional class room by incorporating with different lecture materials.

Bateman, Brooks, McCalla and Brusilovsky [9] outlined their experience about tagging in e-learning application. They described that tagging is prominently different from web annotating. Web annotation is divided into two main categories. One web annotation technique circulates around single user while other relates to the exchange of information and knowledge among different users. Tagging enables its users to browse and allocate the resources in a simple and efficient manner. Tagging in multimedia will become more valuable when a user can tag not only the video but also can tag the lecture slides provided with the videos.

Strohmaier, Korner and Kern [10] described about the reasons of tags assigned by the users. They also explained about the user's inspiration in tagging. Research shows that users are highly motivated by producing fewer descriptive tags and the tag clouds help in offering a non-primitive approach. This approach facilitates with an easy navigation to variety of resources.

\section{ISSUES WITH CURRENT E- LEARNING SYSTEMS}

Traditional class rooms based learning has merely switched into an e-learning system. This e-learning system is termed as "Course Management System (CMS)". It is a platform through which instructors can manage various courses via Web. CMS includes content management, administration of record and providence of education or learning through different set of courses. Traditional e-learning applications have numerous drawbacks or issues as described below. By observing these issues in already existing e-learning applications can become helpful in developing better learning environment.

\subsection{Text-based learning}

Currently, e-learning applications comprises of textual based learning. Applications enriched with textual learning are unable to gain the attention of learners. Studies have also proved that technical and verbal skills cannot be developed, into learners, by using such textual or image based e-learning applications [11].

\subsection{Isolated Environment}

E-learning application provides an isolated communication environment. Its competence level is limited for interactive elearning applications. Primitive e-learning application allows only course instructors with the authority of uploading certain course related notes or materials. These applications are not provided by any discussion platform for learners. Learners have to work under restricted environment. If learners have any query regarding uploaded lecture material then he/she relies on two options. Either to negotiate with course instructor by face and resolve query or ask via e-mail address and wait for the instructor's response.

\subsection{Pre-defined Actions}

E-learning applications specifically CMS facilitates with the pre-programmed set of controls for the scheduling the course, its lecture notes and other course related tutorials. In CMS, lecture notes/materials linked to certain file formats such as Doc file, PowerPoint slides, and PDF lectures. Assessment of any learner is also performed by uploading quizzes, or other grade sheets etc. In other words, traditional CMS maintains only textual data.

\subsection{Flexibility Limitation}

Traditional CMS has provided the students/learners with the limited flexibility. It means that students/learners have been assigned with the limited role and they have to perform certain actions in order to access materials provided with course. The learners couldn't participate in the uploaded materials. In other words, we can say that course instructor is unaware of the response from distant learner. 


\subsection{In-efficient Facility to Search}

Another biggest issue of existing e-learning applications is the lack of appropriate searching facility for educational documents. The main reason of in-efficiency in searching is the distribution of large amount of data across the web. The immense distribution sometimes confuses the students/learners in rightful selection of course contents or information. Thus the large amount of data can become a source of misguidance for learners.

\subsection{Poor Knowledge Management Paradigm}

E-learning applications are lagging behind in terms of knowledge management paradigm. No doubt managing large amount of data is difficult and becomes more difficult when to handle it on web. That's why CMS system always raises a question mark on its efficiency.

\subsection{Absence of Historicity Elements}

E-learning applications don't provide the data history table for the uploaded documents or lectures. So the learners are uninformed of latest uploaded lectures unless and until they visit that source by themselves.

\subsection{Usability}

It is a major issue of existing CMS applications. If an e-learning application's usability is not enough than it stops its whole process. Complex interfaced CMS applications also results into students' frustration and lack of usability.

\subsection{Deficiency of Socialization}

It is difficult to form the community of learners via web because of the distance. Therefore people found themselves forlorn while learning via internet.

\subsection{Lack of Appreciation}

E-learning in different universities doesn't have appreciation tools such as "like" or "rating" etc. According to the different researchers these tools can become helpful in creating the positive reputation of virtual learning. These tools can play an important role for the rightful selection of learning contents.

By concluding this section, hence it is proved that learners cannot rely on traditional approaches of course management for seeking knowledge. Course Management System needs to be enhanced and it should be assigned to provide real backup for class room learning. CMS should focus on students and learning relatively higher than courses. According to the survey it is also proven that students want to have their own profile in CMS and ownership of the profile. They want to study under social learning environment as compared to blackboard style learning [12]. The teamwork of Web 2.0 tools and CMS can be used to provide social and user-centric e-learning application. Web 2.0 tools will play an important role in enhancing the existing course management e-learning applications.

\section{RESEARCH METHODOLOGY: SURVEY}

By analyzing all possible current issues of e-learning applications, a questionnaire based survey is conducted from the personnel associated with education. In this survey learners, who participated, have different age groups but majority are between the age group of 21 to 25 years as mentioned in Graph 1. Survey along with the learners' response is listed in Table1.

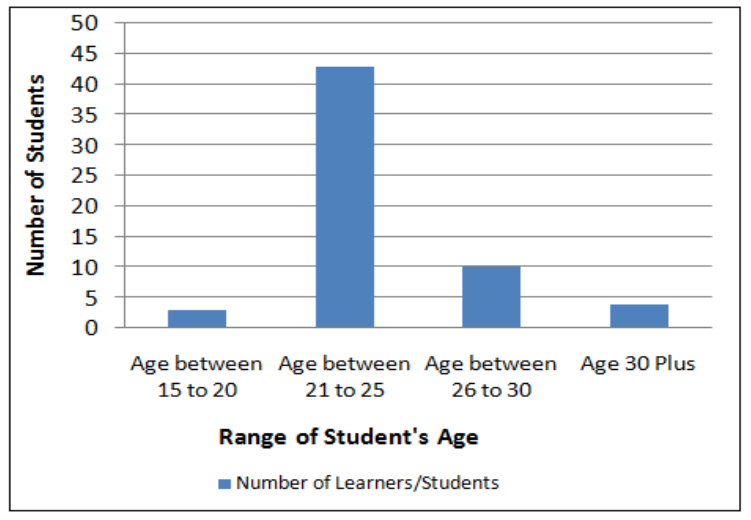

Graph 1. Range of Students Age

Table 1. Questionnaire with Learners Response

\begin{tabular}{|c|c|c|}
\hline Questions & Options & $\begin{array}{l}\text { Responses } \\
(\%)\end{array}$ \\
\hline What is your gender? & $\begin{array}{l}\text { Male, } \\
\text { Female }\end{array}$ & $\begin{array}{l}M=57 \% \\
F=43 \%\end{array}$ \\
\hline \multirow{3}{*}{$\begin{array}{l}\text { What is your area of } \\
\text { specialization? }\end{array}$} & \multirow{3}{*}{$\begin{array}{l}\text { Computer } \\
\text { Sci. } \\
\text { Software } \\
\text { Engg. } \\
\text { Any Other }\end{array}$} & 5 participants \\
\hline & & 25 participants \\
\hline & & $\begin{array}{l}20 \\
\text { participants }\end{array}$ \\
\hline \multirow{2}{*}{$\begin{array}{l}\text { What is your current } \\
\text { status? }\end{array}$} & Student & 45 students \\
\hline & Teacher & 5 teachers \\
\hline $\begin{array}{l}\text { In which program you } \\
\text { are currently enrolled? }\end{array}$ & \multicolumn{2}{|c|}{$\begin{array}{l}50 \% \text { Software Engg, } 20 \% \\
\text { with other engg degree, } 15 \% \\
\text { computer science, } 10 \% \\
\text { management, } 5 \% \text { medical }\end{array}$} \\
\hline \multirow{3}{*}{$\begin{array}{l}\text { What is your highest } \\
\text { degree qualification? } \\
\text { (year education) }\end{array}$} & $12-14 \mathrm{yrs}$ & $5 \%$ \\
\hline & $14-16$ yrs & $70 \%$ \\
\hline & 16 plus yrs & $25 \%$ \\
\hline $\begin{array}{lrr}\text { Have } & \text { you } & \text { ever } \\
\text { experience } & \text { any } & \text { e- } \\
\text { learning } & \text { application } \\
\text { before? } & & \\
\end{array}$ & (Yes, No) & $\begin{array}{l}\text { Yes }=90 \% \\
\text { No }=10 \%\end{array}$ \\
\hline \multirow{3}{*}{$\begin{array}{l}\text { In your opinion how } \\
\text { much e-learning } \\
\text { application is beneficial? } \\
(\text { Very=V, Slight= } \mathrm{S} \text { ) }\end{array}$} & V. beneficial & \multirow{3}{*}{$\begin{array}{l}\text { V. } \\
\text { beneficial=97 } \\
\% \\
\text { S. } \\
\text { beneficial=2 } \\
\% \\
\text { V. less=1\% }\end{array}$} \\
\hline & S. beneficial & \\
\hline & V. less & \\
\hline $\begin{array}{l}\begin{array}{l}\text { Do you like already } \\
\text { existing } \\
\text { applications? }\end{array} \\
\text { e-learning }\end{array}$ & (Yes, No) & $\begin{array}{l}\text { Yes }=22 \% \\
\text { No }=78 \%\end{array}$ \\
\hline $\begin{array}{l}\text { Do you have any idea } \\
\text { about Web } \\
\text { technology? }\end{array}$ & (Yes , No) & $\begin{array}{l}\text { Yes }=80 \% \\
\mathrm{No}=20 \%\end{array}$ \\
\hline $\begin{array}{l}\text { Name those rocial } \\
\text { networking websites } \\
\text { which you often use? } \\
\text { (Twitter, YouTube, } \\
\text { Facebook, Google Plus, } \\
\text { Digg, and Flickr) }\end{array}$ & \multicolumn{2}{|c|}{$\begin{array}{l}\text { Almost } 100 \% \text { votes for } \\
\text { Facebook, YouTube. While } \\
5 \% \text { to } 10 \% \text { also use twitter } \\
\text { and Google Plus as well }\end{array}$} \\
\hline \multirow{2}{*}{$\begin{array}{l}\text { How often you use these } \\
\text { social networking } \\
\text { websites? }\end{array}$} & $\begin{array}{l}\text { Once in a } \\
\text { day }\end{array}$ & $45 \%$ \\
\hline & \begin{tabular}{ll|}
$\begin{array}{l}\text { More than } \\
\text { once }\end{array}$ & \\
\end{tabular} & $55 \%$ \\
\hline
\end{tabular}




\begin{tabular}{|c|c|c|}
\hline \multirow{7}{*}{$\begin{array}{l}\text { Are you familiar with } \\
\text { Web } 2.0 \text { tools such as: } 1 . \\
\text { Tagging } \quad \text { 2.Video } \\
\text { Podcasting/ podcasting } \\
\text { 3.Liver Bookmarking } \\
\text { (Answer each option) }\end{array}$} & Tagging & $85 \%$ \\
\hline & & $70 \%$ \\
\hline & & \\
\hline & & $90 \%$ Video \\
\hline & Podcasting & Podcasting \\
\hline & Live & $50 \% \quad$ Live \\
\hline & $\begin{array}{l}\text { Bookmarkin } \\
\mathrm{g}\end{array}$ & bookmarking \\
\hline $\begin{array}{l}\text { Which of the above } \\
\text { mentioned Web } 2.0 \\
\text { technology would you } \\
\text { like to be a part of e- } \\
\text { learning application? }\end{array}$ & & $\begin{array}{l}90 \% \quad \text { Video } \\
\text { Podcasting } \\
75 \% \text { Tagging } \\
5 \% \text { Live } \\
\text { Bookmarking } \\
\end{array}$ \\
\hline $\begin{array}{l}\text { How important is the use } \\
\text { of video based social } \\
\text { networking and other Web } \\
2.0 \text { technologies in e- } \\
\text { learning? }\end{array}$ & $\begin{array}{l}\text { (Very } \\
\text { relevant, } \\
\text { Slight } \\
\text { relevant, le } \\
\text { relevant) }\end{array}$ & $\begin{array}{l}\text { Very } \\
\text { Relevant=95\%, } \\
\text { Slight } \\
\text { Relevant }=5 \%\end{array}$ \\
\hline $\begin{array}{l}\text { How often you use social } \\
\text { networking website to } \\
\text { share information } \\
\text { regarding your studies } \\
\text { with friends? }\end{array}$ & & $\begin{array}{l}\text { Rarely } 30 \% \\
\text { students use } \\
\text { to share } \\
\text { information } \\
\text { with friends } \\
\text { once a week }\end{array}$ \\
\hline \multirow{3}{*}{$\begin{array}{l}\text { Who is the most useful } \\
\text { person to whom you } \\
\text { discuss course related } \\
\text { questions? }\end{array}$} & Friends & \multirow{3}{*}{$\begin{array}{l}100 \% \text { thinks } \\
\text { that class } \\
\text { fellows and } \\
\text { course } \\
\text { instructor are } \\
\text { useful to } \\
\text { discuss with. }\end{array}$} \\
\hline & $\begin{array}{l}\text { Course } \\
\text { Instructor }\end{array}$ & \\
\hline & $\begin{array}{l}\text { Class } \\
\text { Fellows }\end{array}$ & \\
\hline $\begin{array}{l}\text { In your opinion, do these } \\
\text { web } 2.0 \text { technologies can } \\
\text { play an important role to } \\
\text { enhance the traditional } \\
\text { CMS? If yes explain? }\end{array}$ & \multicolumn{2}{|c|}{$\begin{array}{l}\text { Almost all of the participated } \\
\text { learners said "YES". The } \\
\text { main reason for them is visual } \\
\text { information can facilitates } \\
\text { more as compared to textual } \\
\text { based learning. Students } \\
\text { found "tag" as a better content } \\
\text { management source. }\end{array}$} \\
\hline $\begin{array}{l}\text { Are you willing to use } \\
\text { Web } 2.0 \text { based e-learning } \\
\text { application? }\end{array}$ & $\begin{array}{l}\text { (yes, no, not } \\
\text { sure) }\end{array}$ & $\begin{array}{l}\text { Yes }=45 \\
\text { students } \\
(90 \%), \text { Not } \\
\text { Sure }=3 \\
\text { No }=2 \\
\end{array}$ \\
\hline $\begin{array}{l}\text { Do you think that your } \\
\text { department should make } \\
\text { use of such Web } 2.0 \\
\text { tools for future learning? }\end{array}$ & & $\begin{array}{l}45 \text { students } \\
\text { said yes out } \\
\text { of } 50\end{array}$ \\
\hline 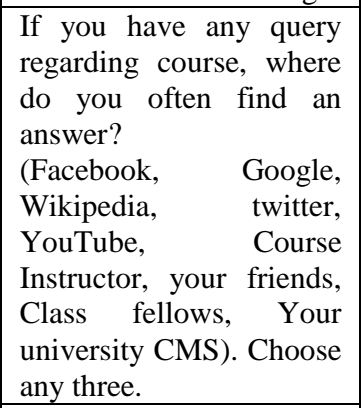 & & 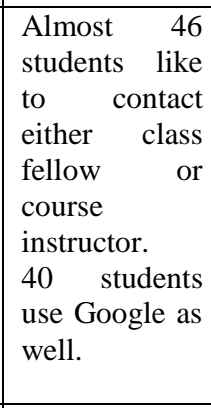 \\
\hline $\begin{array}{lr}\text { Which one } & \text { is your } \\
\text { favourite } & \text { learning } \\
\text { source? Organise them in } \\
\text { descending } \\
\text { Video } & \text { Poder(RSS, } \\
\text { Tagging, } & \text { Social } \\
\text { Networking, } & \text { Wiki, }\end{array}$ & & $\begin{array}{l}95 \% \text { arrange } \\
\text { it as: Video } \\
\text { Podcasting, } \\
\text { Tagging, } \\
\text { Podcasting, } \\
\text { Wiki, Social } \\
\text { Networking, }\end{array}$ \\
\hline
\end{tabular}

\begin{tabular}{|c|c|c|}
\hline Podcasting) & & RSS \\
\hline $\begin{array}{l}\text { Which learning method } \\
\text { is least interesting? } \\
\text { (Audio lectures, Text, } \\
\text { Video lectures ) }\end{array}$ & \multicolumn{2}{|c|}{$\begin{array}{l}90 \% \text { said text based learning } \\
\text { methodology as a difficult and } \\
\text { boring source for } \\
\text { learners/students. }\end{array}$} \\
\hline $\begin{array}{l}\text { Which learning method } \\
\text { is most interesting? } \\
\text { (Audio lectures, Text, } \\
\text { Video lectures ) }\end{array}$ & \multicolumn{2}{|c|}{$\begin{array}{l}96 \% \text { said video lectures are } \\
\text { interesting sources of } \\
\text { learning. }\end{array}$} \\
\hline $\begin{array}{l}\text { What are the major } \\
\text { issues of existing e- } \\
\text { learning applications? } \\
\text { Write any two? }\end{array}$ & \multicolumn{2}{|c|}{$\begin{array}{l}90 \% \text { said Massive amount of } \\
\text { text. Mathematical or other } \\
\text { problems cannot be solve } \\
\text { through text, } 84 \% \text { No } \\
\text { interactivity with course } \\
\text { instructors, } 78 \% \text { Poor data } \\
\text { management, } 60 \% \text { in- } \\
\text { appropriate search facility for } \\
\text { learning contents }\end{array}$} \\
\hline $\begin{array}{l}\text { What would be the } \\
\text { possible solution of such } \\
\text { issues? }\end{array}$ & & $\begin{array}{l}\text { Practical } \\
\text { Videos, } \\
\text { Discussion } \\
\text { Environment, } \\
\text { Search by Tag } \\
\end{array}$ \\
\hline $\begin{array}{l}\text { Do you think tagging is } \\
\text { helpful way to manage } \\
\text { and search data? (If yes } \\
\text { then proceed to next } \\
\text { question else skip it) }\end{array}$ & Jo) & $90 \%$ Yes \\
\hline $\begin{array}{l}\text { Explain why we need } \\
\text { tagging based web } \\
\text { application? How we can } \\
\text { use tags to improve this } \\
\text { e-learning } \\
\text { application. }\end{array}$ & $\begin{array}{l}\text { According to } \\
\text { can help them } \\
\text { contents by } \\
\text { words. Major } \\
\text { that if we deve } \\
\text { which we can } \\
\text { and give ney } \\
\text { application it } \\
\text { students to eas } \\
\text { content wi } \\
\text { keywords. }\end{array}$ & $\begin{array}{l}\text { learners, tags } \\
\text { to search data } \\
\text { using simple } \\
\text { of them said } \\
\text { lop a system in } \\
\text { see all the tags } \\
v \text { tags to our } \\
\text { will help other } \\
\text { ily identify data } \\
\text { th different }\end{array}$ \\
\hline $\begin{array}{l}\text { Would you like to } \\
\text { prototyping testing surve } \\
\text { Interview) and Evaluati } \\
\text { based E-learning web ap } \\
\text { No) }\end{array}$ & $\begin{array}{l}\text { part in } \\
\text { face to face } \\
\text { of web } 2.0 \\
\text { ation? (Yes, }\end{array}$ & $\begin{array}{l}\text { Yes }=45 \% \\
\mathrm{No}=55 \%\end{array}$ \\
\hline $\begin{array}{l}\text { What web } 2.0 \text { features you } \\
\text { see in e-learning web app } \\
\text { as Tagging, Wiki, } \\
\text { podcasting, Podcastir } \\
\text { networking, searching b } \\
\text { Events? }\end{array}$ & $\begin{array}{l}\text { vould like to } \\
\text { cation? Such } \\
\text { SS, Video } \\
\text { Social } \\
\text { tags, Blog, }\end{array}$ & $\begin{array}{l}\text { The result is } \\
\text { shown in the } \\
\text { graphical } \\
\text { notation to } \\
\text { make it } \\
\text { understandabl } \\
\text { e for reader. } \\
\text { View Graph } 2 \\
\text { for the results. }\end{array}$ \\
\hline
\end{tabular}

The graphical notation for last question of the survey is mentioned in Graph 2. From this graph and this survey, it is concluded that learners have shown more interest in video based learning and they want to search by using tag in large amount of data. The new e-learning application should be composed most favorite Web 2.0 tools of learners so that it can get acceptance from learners. 


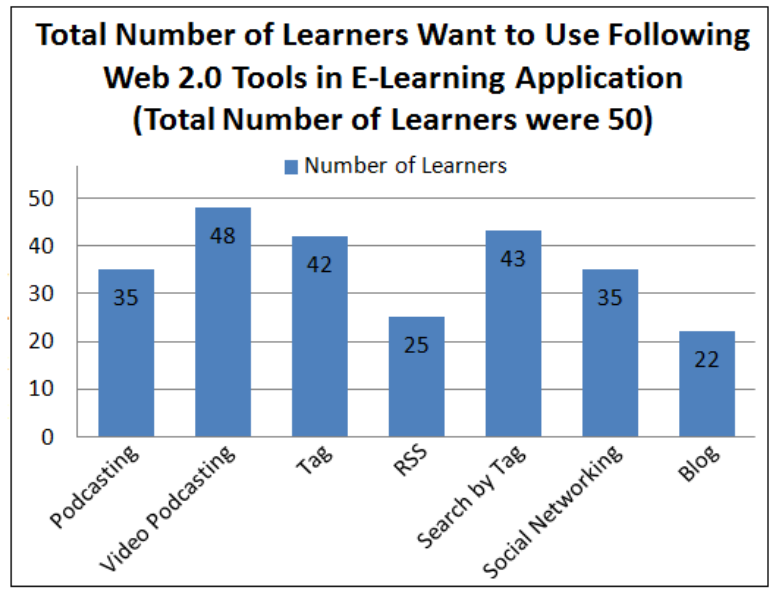

Graph 2. Learner's Vote to Use different Web 2.0 tools in elearning application

\section{VIRTUAL LEARNER 2.0}

An evolutionary prototype process model is used for enhanced e-learning application "Virtual Learner 2.0". The main reason of selecting evolutionary prototype model is due to its better efficiency and progress is always visible at the completion of any iteration [13]. The evolutionary prototype model works in four stages as shown in Figure 2.

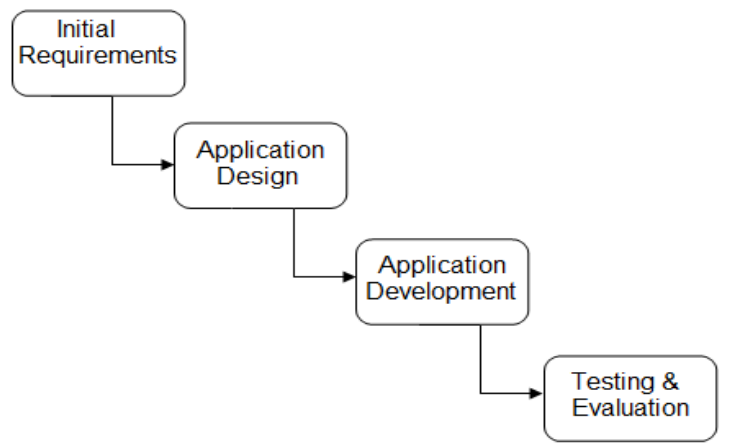

Fig 2: Evolutionary Prototype Process Model for Virtual Learner 2.0

From survey initial requirements were obtained for enhanced elearning application and also became obvious that students want to have Web 2.0 tools in e-learning application. System is designed by considering current issues and trends in e-learning applications. Development of application is performed in small iterations. Several Web 2.0 tools are implemented in this elearning application including discussion forum, RSS, Video Podcasting, Tagging etc.

\subsection{Evaluation}

It is the most important portion of research as it will show the results whether the proposed system conforms to the standards of learners/students or not and will also help in finding out the effectiveness of Web 2.0 tools in e-learning application. The main purpose is:

a) To evaluate the impact of using video based learning in education (Video Podcasting).

b) To evaluate the importance of tags in Web 2.0 based e-learning applications and improvement in data searching through this tool (Tags and Cloud Tags). c) To evaluate the significance of comments and discussions on different data contents (Comments and Discussion Forum)

d) To evaluate the usability of this Web 2.0 based elearning application.

Learners were asked to evaluate this application and this evaluation will show us whether Virtual Learner 2.0 achieves its goals or not.

\subsubsection{Evaluate the impact of Video based Learning in Education (Video Podcasting)}

The major purpose of "Virtual Learner 2.0" is to evaluate the impact of video based learning or Video Podcasting in our education system. Students are bored of traditional e-learning applications and they want to use social networking based elearning application. Data was gathered from the survey and almost all students were in favor of video based learning. So "Video Podcasting" technique is implemented in Virtual Learner 2.0. In this application not only course instructor but also the students/learners can upload their videos and maintain their own list of videos. Learners can view their own uploaded video or can select from the most recently uploaded videos at any time. As shown in Fig.3, learner or course instructor can watch the video and they can also download it on local computers.

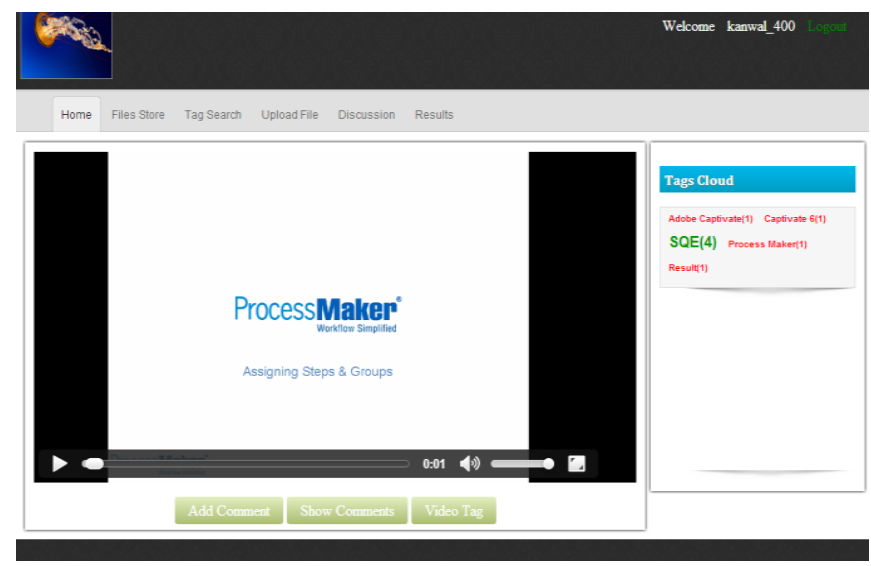

Fig 3: Video Upload in Virtual Learner 2.0

In this File store contains list of all the documents including videos which learners uploaded. For example in Fig.4 User "kanwal_400" uploaded new video. The list will also display some additional features such as play, download, add tags and date time of uploaded videos.

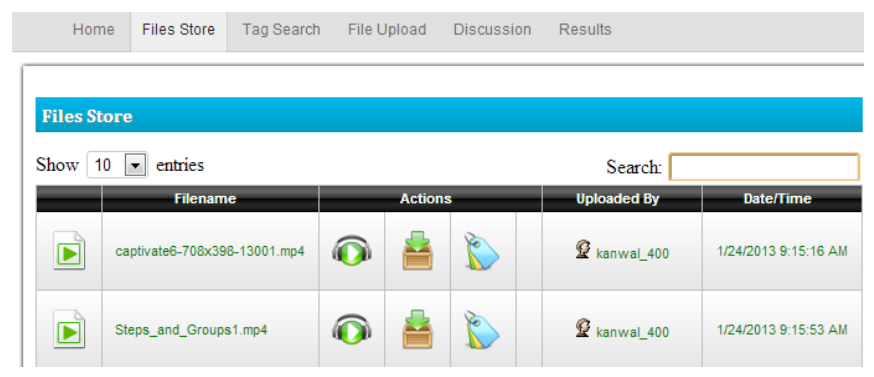

Fig 4: File Store

The students, who participated in the evaluation of this application, have shown positive feedback. According to them:

a) It is a best revision technique. We can play/pause videos any time and we can leave comments as well. 
b) The discussion feature integrated with all video lectures makes this e-learning application very active.

c) Take less time to upload the lecture and can easily view these lectures.

d) We can watch video lectures from any position while in class room based education we have to sit and listen to the course instructor with full concentration.

\subsubsection{Evaluate the importance of tags in Web 2.0} based e-learning application and improvement in data search (Tag and Cloud Tag)

Another most important Web 2.0 tool is used in proposed application "Virtual Learner 2.0". The purpose of tags and cloud tags is to observe the searching efficiency. Fig. 5 shows the successful entry of tag in document by using Virtual Learner 2.0. Multiple tags are added into any document. Learners can not only create new tags for any document but also can use already existing tags of corresponding document.

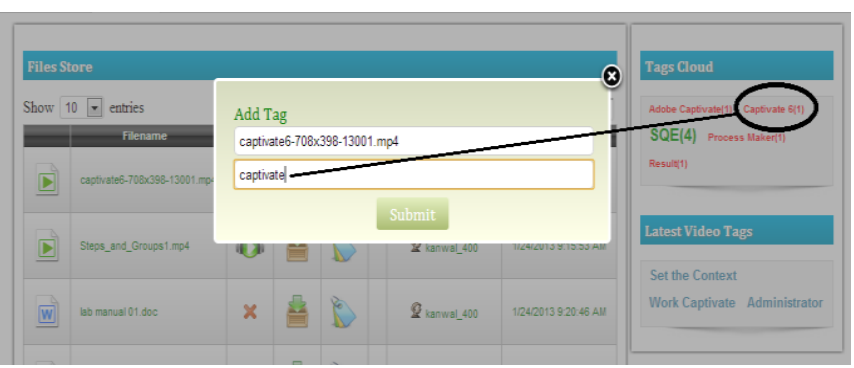

Fig 5: Successful Tag Entry in Document

Evaluation participants viewed tags and cloud tags as an efficient source of organizing the resources. The efficiency of any system relates to its maximum capability of providing competent organisation of every resource. The efficiency of cloud tag means Web 2.0 tool which provides an effort less searching and organisation of data contents. Cloud tag represents the broad view of entire application data content within one page. Cloud tagging provides the maximum searching within shortest possible time. Example of cloud tag is displayed in Fig. 6. In this tag cloud each tag also shows its frequency or usage of that tag name.

\begin{tabular}{l} 
Tags Cloud \\
\hline Adobe Captivate(1) Captivate 6(1) \\
SQE(4) Process Maker(2) \\
Result(1) \\
\hline
\end{tabular}

Fig 6: Cloud Tag of Virtual Learner 2.0

Additionally, learners responded that tagging provides easy, stress free and time saving search facility. Simple keyword searching is not a good approach for finding data. Cloud tag provides the simplified approach of searching. Just by clicking any keyword displays the list of all the documents. For example, in Fig. 7, user just clicks the option of "SQE" from the cloud and displays all the results matching with keyword while by simple search "SQE" shows no result as shown in Fig.8. The whole process takes some seconds. So searching contents through tag cloud takes lesser time as compared to normal search.

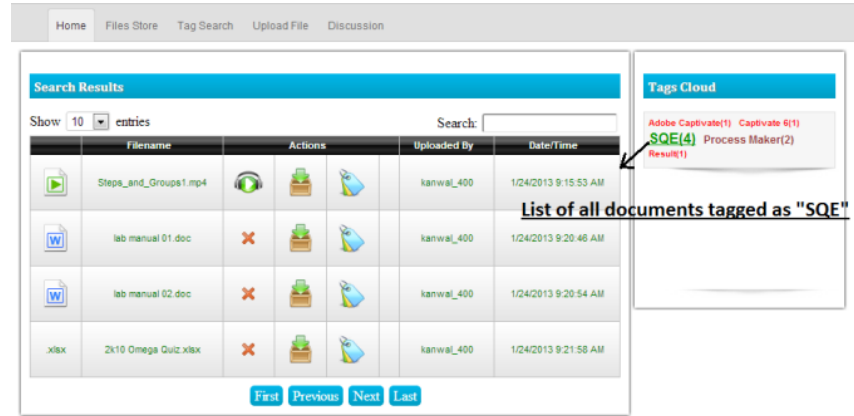

Fig 7: Example of Search by using Cloud Tag

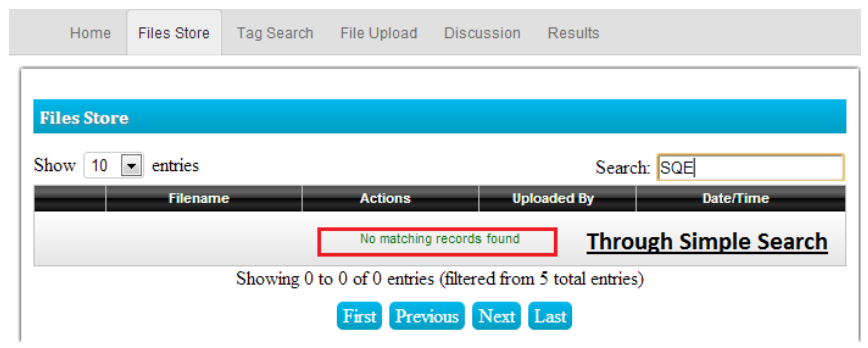

Fig 8: Example of Simple Search

\subsubsection{Evaluate the Significance of Comments and Discussions}

Virtual Learner 2.0 also incorporates with Web2.0 tools named as comments and discussion forums. These tools improve collaborative learning and many queries can be resolved through these tools. By inserting comments in video lectures improve social learning as shown in Fig. 9. The learners, who participated in evaluation, also found these tools very effective in e-learning application.

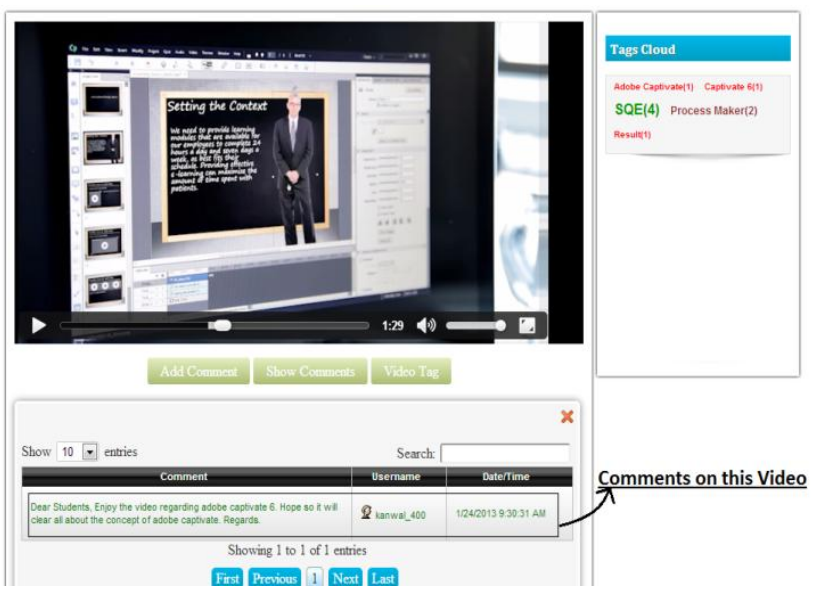

Fig 5: Comments on Videos

Discussion forum is a multi-disciplinary tool which means that it consists of different discussion threats at same place. 


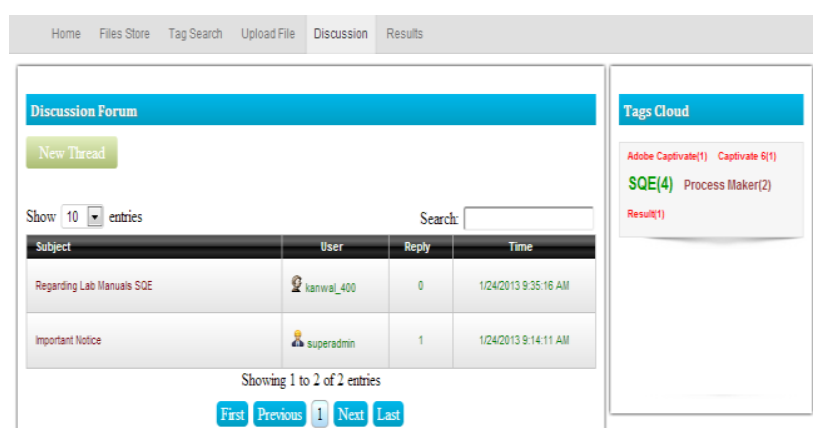

Fig 10: Discussion Forum in Virtual Learner 2.0

Fig.10 highlights the discussion forum of Virtual Learner 2.0. The forum consists of different threads and also displays some other information such as discussion creator name, discussion date/time, no. of replies count etc. Any learner can join the discussion of particular topic by clicking on the "Subject" of that discussion.

\subsubsection{Evaluate the Usability of Virtual Learner 2.0}

Usability is the most important non-functional requirement. As discussed earlier, if the system is not usable enough than it stops whole process learning and ends up with the failure of the system. Usability of Virtual Learner 2.0 is evaluated by comparing it with already existing course management elearning application. Make a checklist of some parameters then compare Web 2.0 based e-learning application with the traditional Course Management System. The comparison is mentioned in Table 2.

Table 2. Usability Evaluation of Virtual Learner 2.0

\begin{tabular}{|l|c|c|}
\hline \multicolumn{1}{|c|}{ Parameters to Test } & $\begin{array}{c}\text { Existing } \\
\text { e-learning } \\
\text { Apps }\end{array}$ & $\begin{array}{c}\text { Virtual } \\
\text { Learner } \\
\mathbf{2 . 0}\end{array}$ \\
\hline 1. Video based Learning & No & Yes \\
\hline $\begin{array}{l}\text { 2. Collaborative } \\
\text { Environment }\end{array}$ & No & Yes \\
\hline 3. Uploading Restrictions & Yes & No \\
\hline $\begin{array}{l}\text { 4. Students Ownership } \\
\text { Profile }\end{array}$ & No & Yes \\
\hline $\begin{array}{l}\text { 5. Tag any Documents } \\
\text { 6. Search by Tag }\end{array}$ & $\begin{array}{c}\text { Tag Facility } \\
\text { doesn't exist }\end{array}$ & Yes \\
\hline $\begin{array}{l}\text { 7. Cloud Tag of } \\
\text { Application }\end{array}$ & No & Yes \\
\hline $\begin{array}{l}\text { 8. Proper Knowledge } \\
\text { Management }\end{array}$ & No & $\begin{array}{c}\text { Yes } \\
\text { (through } \\
\text { Cloud } \\
\text { Tag) }\end{array}$ \\
\hline $\begin{array}{l}\text { 9. Presence of Historical } \\
\text { Element }\end{array}$ & No & $\begin{array}{c}\text { Yes } \\
\text { (For all the } \\
\text { uploaded } \\
\text { documents } \\
\text { Instructors }\end{array}$ \\
\hline $\begin{array}{l}\text { 10. Appreciation Words } \\
\text { e.g. Comments etc }\end{array}$ & No & Yes \\
\hline 11. Comment Facility to & Both \\
\hline
\end{tabular}

\begin{tabular}{|c|c|c|}
\hline $\begin{array}{l}\text { 12. Discussion Forum } \\
\text { for Both Students } \\
\text { and Instructors }\end{array}$ & $\begin{array}{c}\text { Only } \\
\text { Instructor }\end{array}$ & Both \\
\hline $\begin{array}{l}\text { 13. Availability of } \\
\text { Socialization }\end{array}$ & No & $\begin{array}{l}\text { Yes (due } \\
\text { to Web } 2.0 \\
\text { tools) }\end{array}$ \\
\hline
\end{tabular}

\section{CONCLUSIONS}

Traditional Course Management System is unable to fulfill the requirements of large and diversified society of learners. For this purpose a system, Virtual Learner 2.0, is proposed. The system is developed according to learner's choice. Due to the popularity of different Web 2.0 tools, Learners show more deviation towards visual and socialized e-learning approaches as compared to traditional textual based learning. This elearning system is developed by using evolutionary prototype process model and accomplished the task of satisfying students/learners. Learners evaluated different Web 2.0 features like the impact of video based learning in education. They also evaluated the effectiveness of using tags, cloud tags, comments and discussion forum in Virtual Learner 2.0. The usability of this new Web 2.0 based application is evaluated by comparing it with already existing e-learning applications. Learners have found that Web 2.0 tools are highly compatible and most significant for educational system. They viewed that injecting Web 2.0 techniques into our educational system fosters a userfriendly, flexible, efficient and reliable learning environment. They further stated that Virtual Learner 2.0 plays an important role in solving many riddles for students/learners.

\section{ACKNOWLEDGMENT}

I affectionately, would like to thank my respectable supervisor Muhammad Nadeem Majeed for his true guidance. And special thanks to Dr. Adeel Akram for his useful suggestions and experience. Their ideas helped me a lot in not only development of project "Virtual Learner 2.0" but also in the completion of this research paper.

\section{REFERENCES}

[1] Michael G. Moore, Greg Kearsley. 2005. Distance Education: A Systems View of Online Learning", pp. 7-10

[2] Chen Xin 2009. E-learning Applications and Challenges in 2nd International Conference on Future Information Technology and Management Engineering, pp. 580-583

[3] Antonio Bartolomé 2008. Web 2.0 and New Learning Paradigms

[4] Liangtao Yang 2012. Application of E-Learning in Community Education in International Symposium on Information Technology in Medicine and Education, pp. $35-38$

[5] Lina Chen 2008. About e-Learning Application in Communication teaching in $7^{\text {th }}$ International Conference on Web-based Learning, pp. 87-92

[6] Katerina Papanikolaou, Stephanos Mavromoustakos 2012. Developing Adaptive e-Learning Systems based on Web 2.0 in International Conference on Information Society (iSociety 2012), pp. 370-375

[7] Jonathan Copley 2007. Audio and video podcasts of lectures for campus based students: production and evaluation of student use in Innovations in Education and Teaching International Vol. 44, No. 4, pp. 387-399 
[8] J.P. Shim, Jordan Shropshire, Sungmin Park, Howard Harris, Natalie Campbell 2007. Podcasting for e-learning, Communication and delivery in Industrial Management \& Data Systems, Vol. 107, No. 4, pp. 587-600

[9] Scott Bateman, Christopher Brooks, Gordon McCalla and Peter Brusilovsky 2007. Applying Collaborative Tagging to E-Learning in Proceeding of ACM, Vol. 3, Issue 4. Banff, Canada.

[10] Markus Strohmaier, Christian Korner, Roman Kern 2010. Why Do Users Tag? Detecting Users' Motivation for Tagging in Social Tagging Systems in Proceedings of the 4th International Association for the Advancement of Artificial Intelligence Conference on Weblogs and Social Media, pp. 339-342
[11] Shank, P 2011. The Online Learning Idea Book: Proven Ways to Enhance Technology-Based and Blend Learning 2nd edition. San Francisco: Pfeiffer Publisher, pp. 4-19.

[12] Nathan Garrett, Brian Thoms, Nimer Alrushiedat and Terry Ryan 2009. Social ePortfolios as the new course management system in Proceeding of 'On the Horizon', Vol. 17 Issue: 3 pp. $197-207$

[13] Lenz, G. and Moeller, T 2004. Introducing software engineering. NET.A complete development cycle Pearson Education, pp. 39-41. 